\title{
Profundal-Pelagic Macrocrustacean Abundance in Boreal Lakes Before and After Experimental Clearcut Logging
}

\author{
R. L. France \\ Integrated Environmental Management, Department of Engineering, NSAC, Truro, Nova Scotia, Canada \\ Department of Graduate Studies, Dalhousie University, Halifax, Nova Scotia, Canada \\ Center for Technology and the Environment, Harvard University, Cambridge, Massachusetts, USA
}

(received in April, 2011, accepted in June, 2011)

\begin{abstract}
A sampling program of 9 years revealed that the opossum shrimp Mysis relicta and the amphipod Diporeia hoyi were present in three boreal lakes in northwestern Ontario, Canada regardless of whether watershed forests were left completely intact, left as only a narrow buffer strip, or were nearly completely removed through experimental clearcutting. In fact, Diporeia were actually found to be more abundant in all lakes following logging. And the decline in Mysis abundance observed in one of the lakes occurred well before the initiation of timber removal. Consequently, it appears that these keystone, glacial-relic species of macrocrustaceans are not negatively impacted by clearcutting. This is in direct contrast to the hypersensitivity and extirpation of these same species which has been previously demonstrated in acidifying boreal lakes.

Key words: pelagic macrocrustacean abundance, boreal lakes, clearcut logging.
\end{abstract}

\section{Introduction}

With an annual removal rate of nearly $1 \%$, the scale of timber harvesting in the boreal forest of Canada, mostly through clearcutting operations, is truly enormous (Perera et al. 2000). The great majority of research on the influences of logging on aquatic communities comes from studies on small streams, often conducted in mountainous regions and which consequently may have only limited applicability to situations in the boreal forest (Carignan \& Steedman 2000, Pinel-Alloul et al. 2002). In contrast, studies of the implications of logging on the limnology and aquatic ecology of boreal lakes are relatively infrequent (Steedman et al. 2004). In general, alterations in the abundance or biology of fishes in boreal lakes due to watershed or riparian clearcutting seem to be relatively minor or nonexistent (Berube \& Levesque 1998, Rask et al. 1998, St. Onge \& Magnan 2000, Tonn et al. 2003, Bertolo and Magnan 2006). In the few cases where changes in fish growth have been detected, some of these researchers have contended that this might be accounted for by some unmeasured alteration in the pelagic foodweb. There is heuristic evidence to support such an illation.
In the last decade and a half we have learned that the physical-chemical environment of lakes can be susceptible to timber harvesting operations, some of which might be expected to affect the pelagic zone. Erosion from construction of roads (France 2002, Steedman \& France 2000) and removal of forests (France 1997a, France et al. 1998) can contribute to an increased accumulation of sediments in profundal zones (Blais et al. 1998). Increased sedimentation often has deleterious impacts upon aquatic organisms. At the same time, lakes in clearcut watersheds frequently display elevated concentrations of total phosphorus (Rask et al. 1998, France et al. 2000a, Carignan et al. 2000, Winkler et al. 2009). Due to the 'bottom-up' resource mediation of zooplankton in boreal lakes, it is possible that elevated nutrients will result in more phytoplankton and therefore more zooplankton. However, clearcutting also simultaneously increases the watershed export of DOC to lakes (Rask et al. 1998, France et al. 2000b, Carignan et al. 2000, Winkler et al. 2009) which, because transparency is dependent on organic colour in such lakes, might be expected to decrease the euphotic zone and thus negatively affect 
phytoplankton and their planktoivores. On the other hand, increased colour in lakes may provide some protection against UV-B toxicity and thus might improve the environment for plankton (France et al. 2000b). Reduced inputs of allochthonous leaf litter and the resulting decreased release of nutrients and carbon from lechate following clearcutting (France et al. 1996, 1997) also has the potential to affect pelagic productivity (France and Peters 1995). Finally, riparian tree removal can increase over-water wind speeds which may lead to thermocline deepening and an alteration in the thermal habitat of lakes (France 1997b) which could influence plankton biodiversity and abundance (Scully et al. 2000).

Although synoptic surveys and paleolimnological research have investigated the plankton communities of boreal lakes in logged watersheds (Paterson et al. 1998, Rask et al. 1998, Planas et al. 2000, Scully et al. 2000, Patoine et al. 2000, 2002a,b, Ghadouani et al. 2006, Rasanen et al. 2007, Winkler et al. 2009, Hausmann \& Pienitz 2009), no such work has investigated how keystone macrocrustaceans in the pelagic zone might respond to clearcutting.

The purpose of the present study was to provide the first documentation of the abundance response of two important glacial relic species: the opossum shrimp Mysis relicta and the amphipod Diporeia hoyi to experimental clearcut logging around boreal lakes.

Selection of these particular study species is not arbitrary but reflects three important attributes of their ecology. First, the normally high abundance of both species in boreal lakes means that they can dominate the profundal zoobenthic fauna in terms of biomass (Nero 1982, P. Olesiuk, Can. Dept. Fisheries \& Oceans, unpubl. data). Second, both species play an important role in regulating food web dynamics and energy flow both through their feeding on lower trophic categories and their recycling of detritus (Green 1971, Nero \& Sprules 1986; France et al. 1995, Chipps et al. 2000) as well as their predation by commercially important fishes (Green 1971, France \& Steedman 1996, Guiguer et al. 2002, Hondorp et al. 2005). And third, both species are recognized to be extremely sensitive to anthropogenic acidification of boreal lakes (Nero \& Schindler 1983, Schindler 1990, P. Olesiuk, unpubl. data), and possibly may have a similar potential to serve as early warning indicators for monitoring the aquatic effects of clearcutting.

\section{Methods}

\subsection{Study Lakes and Experimental Forestry}

The study area $\left(49^{\circ} 08^{\prime} \mathrm{N} ; 92^{\circ} 09^{\prime} \mathrm{W}\right)$ is situated within the boreal forest of northwestern Ontario, located on the Canadian Shield $45 \mathrm{~km}$ northwest of Atikokan and about $100 \mathrm{~km}$ southeast of the wellknown Experimental Lakes Area. Maps are shown in France et al. (1998), Paterson et al. (1998), Nicholls et al. (2003) and Steedman (2003). Details concerning vegetation, litterfall, topography, and soil properties of this area are presented in France (1997a), France and Peters (1995) and France et al. (1998). The 4 study lakes are small, proximally located, headwater basins characterized by dilute waters, low nutrients, and cold temperatures (Steedman 2000).

In an attempt to investigate the long-term sustainability of industrial forestry practices, a multidisciplinary study was undertaken to follow the limnology and ecology of three boreal lakes whose forests were removed through riparian and watershed clearcutting (Steedman 2000). During 1996, the watersheds of Lakes 26, 39 and 42 were partially clearcut through use of a tracked feller buncher and chainsaws. Harvested trees were dragged to the nearest road for de-limbing. Lake 39 (L39) and L42 experienced extensive watershed (60-70\%) and riparian (40-60\%) disturbance, whereas L26 experienced moderate watershed disturbance (33\%) with no harvesting of riparian trees. L20, which is situated beside and connected to L26 by a small stream, maintained its riparian forest with the only watershed disturbance being that taking place in its L26 sub-basin. During 1998, an additional 19\% of the riparian forest around L42 was removed (which accounted for $3 \%$ of the total watershed area). Also at the same time, trees were harvested beside from the inflowing streams to L26 (which accounted for 15\% of the watershed). During the experimental timber harvest, $5 \mathrm{~km}$ of logging roads were constructed in the watersheds of L39 and L42 and $2 \mathrm{~km}$ of roads were constructed in the watershed of L26. Further details of the experiment can be found in Steedman and Kushneriuk (2000).

\subsection{Macroinvertebrate Sampling}

Two sampling programs were initiated to monitor the abundance of profundal-pelagic macrocrustaceans in the study lakes: (1) intensive collections were made once before and again during and finally after clearcutting in 1992, 1996 and 2000, respectively; and (2) a temporal series of less intensive collections were made during the duration of the land management experiment from 1993 to 2000.

Mysis relicta (henceforth simply Mysis) and Diporeia hoyi (henceforth simply Diporeia) were sampled in October 1992 (France \& Steedman 1996) and October 1996 and October 2000 with use of a meter-square net (Nero 1982) as employed in previous studies (Nero \& Schindler 1983, France et al. 1995). From 12 to 15 vertical hauls were collected from the deepwater centre of each lake when the animals became planktonic at night. Samples were sorted live within $24 \mathrm{hr}$ of collection. For the temporal sampling program,. Mysis and Diporeia were collected in the same fashion with the same metersquare net in September 1993, August 1994, August 1995, August 1997, August 1998, August 1999, and July 2000. Eight vertical hauls were collected in 1993, and 3 hauls made in subsequent years. 


\section{Results}

Due to concordance between the results obtained from the two sampling programs (Table 1) their findings will be examined together. In 1992, amphipods (Diporeia) were found in L39 but not in the other lakes. During the pre-clearcutting years, Diporeia continued to be observed in L39 and were detected in L26 in 1993 and again in 1995. Diporeia were either absent or present at abundances below detection in L42 and L20 during this period. Diporeia were first detected in L42 in 1996 coincident with initiation of experimental logging and also made their first appearance in reference L20 at the same time. For all 3 treatment lakes, Diporeia were more abundant in the last 4 years of sampling (1997 to 2000) after logging compared to the first 4 years (1992 to 1995) before logging.

The abundance of opossum shrimp (Mysis) varied through time across the study lakes. Abundance in each of L20 and L39 were generally comparable from 1992 to 2000. In contrast, Mysis abundance in L42 and in L26 were respectively either consistently smaller or occasionally larger following termination of experimental logging in 1998 compared to values recorded for 1992 and 1993.

Table 1. Profundal-pelagic macrocrustacean abundance (\# $\left.m^{-2} \pm S D\right)$ in boreal lakes from 1992 to 2000. The shorelines and watersheds of Lake 42 and Lake 39 and the watershed of Lake 26 were clearcut during 1996 with further timber harvesting taking place in 1998

\begin{tabular}{|l|l|l|l|l|l|l|l|l|l||}
\hline Date & $\begin{array}{l}\text { Sample } \\
\text { number }\end{array}$ & Lake 42 & Lake 42 & Lake 39 & Lake 39 & Lake 26 & Lake 26 & Lake 20 & Lake 20 \\
\hline & & Mysis & Diporeia & Mysis & Diporeia & Mysis & Diporeia & Mysis & Diporeia \\
\hline 1992 Oct & $12-15$ & $260 \pm 87$ & 0 & $98 \pm 45$ & $2 \pm 1$ & $47 \pm 21$ & 0 & $57 \pm 10$ & 0 \\
\hline 1993 Sept & 8 & $284 \pm 101$ & 0 & $58 \pm 15$ & $2 \pm 1$ & $52 \pm 13$ & $1 \pm 1$ & $45 \pm 23$ & 0 \\
\hline 1994 Aug & 5 & $296 \pm 64$ & 0 & $72 \pm 8$ & $4 \pm 2$ & $5 \pm 2$ & 0 & $34 \pm 25$ & 0 \\
\hline 1995 Aug & 5 & $91 \pm 53$ & 0 & $70 \pm 6$ & $2 \pm 1$ & $29 \pm 4$ & $2 \pm 2$ & $45 \pm 23$ & 0 \\
\hline 1996 Aug & $12-15$ & $105 \pm 96$ & $1 \pm 1$ & $76 \pm 26$ & $4 \pm 2$ & $35 \pm 23$ & $3 \pm 2$ & $34 \pm 21$ & $1 \pm 1$ \\
\hline 1997 Aug & 5 & $98 \pm 21$ & 0 & $72 \pm 20$ & $6 \pm 3$ & $21 \pm 10$ & $2 \pm 2$ & $23 \pm 14$ & $2 \pm 1$ \\
\hline 1998 Aug & 5 & $60 \pm 23$ & $2 \pm 1$ & $69 \pm 39$ & $2 \pm 2$ & $11 \pm 3$ & $1 \pm 1$ & $68 \pm 45$ & $1 \pm 1$ \\
\hline 1999 Aug & 5 & $38 \pm 10$ & $6 \pm 6$ & $60 \pm 28$ & $8 \pm 6$ & $10 \pm 7$ & $2 \pm 1$ & $68 \pm 33$ & 0 \\
\hline 2000 July & 5 & $37 \pm 22$ & $5 \pm 3$ & $56 \pm 33$ & $2 \pm 2$ & $106 \pm 11$ & $6 \pm 3$ & $23 \pm 16$ & $1 \pm 1$ \\
\hline 2000 Oct & $12-15$ & $65 \pm 16$ & $6 \pm 2$ & $75 \pm 24$ & $9 \pm 4$ & $96 \pm 23$ & $8 \pm 4$ & $27 \pm 21$ & $2 \pm 1$ \\
\hline \hline
\end{tabular}

\section{Discussion}

The estimated abundance of both macrocrustacean species were generally comparable between the before/after and the trend sampling programs for near contemporaneous collections made in either 1992 and 1993 or again in 2000. Further, the present findings are in agreement with a completely independent sampling of these two species as part of the comprehensive assessment of the potential implications of logging undertaken in the same lakes over the same time period (R. Steedman, Ont. Min. Nat. Res., unpubl. data). All this gives credence to the reproducibility, if not accuracy, of the present sampling program for assessing potential changes in relative, and possibly even, absolute abundance in the study lakes and is in line with other studies in nearby lakes which have used the same methodology to assess differences in abundance in response to experimental acidification (Nero \& Schindler 1983; P. Olesiuk, unpubl. data).

The abundance of the amphipod Diporeia increased in all three lakes subjected to experimental clearcutting. The most demonstrative alteration in macrocrustacean abundance occurred for the opossum shrimp Mysis in L42 with values in 1999 and 2000 being only a quarter of what they had been in 1992 and 1993. Might any of these changes in macroinvertebrate abundance be related to experimental logging?

The notable increases in abundance of Diporeia observed in L42, L39 and L26 after experimental logging must be considered in relation to the more modest contemporaneous increase in abundance that occurred in reference L20. This implies the possibility of a regional, perhaps climate-induced, influence on the biology of this species. That said, even when this modest increase is subtracted from the more substantial increases observed in the other lakes, there still remains a systematic increase in Diporeia coincident with watershed and/or riparian logging. It is possible that an increased deposition of sediments resulting from accelerated riparian soil erosion (France 1997, 2002, France et al. 1998, Steedman \& France 2000), which will be concentrated in the profundal zone (Blais et al. 1998), may have contributed to more favorable environments for this deposit-feeding amphipod.

In contrast, variability in Mysis abundance is independent of logging. The large declines in abundance observed in L42 occurred between 1994 and 1995. Since experimental logging did not commence around the lake until 1996, this decrease in Mysis abundance cannot be related to forestry operations. Neither substantial alterations in lake chemistry (Steedman 2000), thermal stratification (Steedman \& Kushneriuk 2000), phytoplankton 
community structure (Nicholls et al. 2003), or abundance of zooplanktivorous fishes (R. Steedman, unpubl. data) occurred in L42 at that time which might be invoked to explain the decrease in Mysis abundance. The cause of the precipitous population decline remains unknown.

The tolerance of both these macroinvertebrate species to removal of trees through clearcutting seems reasonable given their evolution as glacial relics in lakes located in a landscape that by its very nature is characterized by a high degree of disturbance. Boreal watersheds repeatedly lose their forests, including riparian trees (France 1997b, Blais et al. 1998, McEachern et al. 2000), through wildfires (Perera et al. 2000). The continued existence of profundal-pelagic amphipods and shrimps in such lakes implies that limnological and biological alterations resulting from watershed disturbance cannot be assumed a priori to be harmful to these species.

The present findings are consistent with other research conducted in these same study lakes on a wide variety of limnological and biological attributes (Blais et al. 1998, Steedman 2000, 2003, Steedman \& Kushneriuk 2000, Steedman \& France 2000, Knapp et al. 2003, Nicholls et al. 2003) as well as synoptic surveys of other plankton (Paterson et al. 1998, Rask et al. 1998, Planas et al. 2000, Scully et al. 2000, Patoine et al. 2000, 2002a,b, Ghadouani et al. 2006, Rasanen et al. 2007, Winkler et al. 2009, Hausmann \& Pienitz 2009) and fishes (Berube \& Levesque 1998, Rask et al. 1998, St. Onge \& Magnan 2000, Tonn et al. 2003, Bertolo and Magnan 2006) in indicating that organisms in boreal lakes can be resilient to removal of the watershed or riparian trees through logging.

Because wildfires often burn to the water's edge, the emulation of such conditions through riparian clearcutting might also pose no serious threat to the survival of these particular species. Further studies of the aquatic effects of sustainable forestry, which by definition is designed to mimic the patterns of natural disturbance characteristic of the boreal landscape, are needed however before a management recommendation of any confidence can be made concerning riparian clearcutting around boreal lakes.

\section{Conclusions}

1. The abundance of two glacial relict species, Mysis relicta and Diporeia hoyi, were monitored for 9 years in 4 boreal lakes in northwestern Ontario, Canada whose watersheds and shorelines had been experimentally logged as part of a large multidisciplinary study.

2. Mysis abundance was found to be independent of clearcut logging. Diporeia actually increased in lakes following timber removal.

3. These two macrocrustacean species are not negatively impacted by clearcutting in direct contrast to their acknowledged hyper-sensitivity to acidification.

\section{References}

BERTOLO, A., MAGNAN, P. Logging-induced variations in dissolved organic carbon affect yellow perch (Perca flavescens) recruitment in Canadian Shield lakes. Canadian Journal of Fisheries and Aquatic Sciences, 2007. Vol. 64. pp. 181-186.

BERUBE, P., LEVESQUE. Effects of forestry clearcutting on numbers and sizes of brook trout, Salvelinus fontinalis (Mitchill), in lakes of the Mastigouche Wildlife Reserve, Quebec, Canada. Fisheries Management and Ecology, 1998. Vol. 5. pp. 123-137.

BLAIS, J.M., FRANCE, R.L., KIMPE, L.E. CORNETT, R.J. Climatic changes in northwestern Ontario have had a greater effect on erosion and sediment accumulation than logging and fire: evidence from ${ }^{210} \mathrm{~Pb}$ chronology in lake sediments. Biogeochemistry, 1998. Vol. 43. pp. 235-252.

CARIGNAN, R., STEEDMAN, R. Impact of major watershed perturbations on aquatic ecosystems. Canadian Journal of Fisheries and Aquatic Sciences, 2000. Vol. 57. pp. 1-4.

CARIGNAN, R., D'ARCY, P., LAMONTAGNE, S. Comparative impacts of fire and forest harvesting on water quality in Boreal Shield lakes. Canadian Journal of Fisheries and Aquatic Sciences, 2000. Vol. 57. pp. 105-117.

CHIPPS, S.R., BENETT, D.H. Zooplanktivory and nutrient regeneration by invertebrate (Mysis relicta) and vertebrate (Oncorhynchus nerka) planktivores: implications for trophic interactions in oligotrophic lakes. Transactions of the American Fisheries Society, Vol. 129. pp. 569-583.

FRANCE, R.L. Factors influencing sediment transport from logging roads near boreal trout lakes (Ontario, Canada). In France, R. (ed.) Handbook of Water Sensitive Planning and Design, 2002. CRC Press.

FRANCE, R.L. Potential for soil erosion from decreased litterfall due to riparian cleracutting: implications for boreal forestry and warm- and cool-water fisheries. Journal of Soil and Water Conservation, 1997a. Vol. 52. pp. 452-455.

FRANCE, R.L. Land-water linkages: influences of riparian deforestation on lake thermocline depth and possible consequences for cold stenotherms. Canadian Journal of Fisheries and Aquatic Sciences, 1997b. Vol. 54. pp. 1299-1305.

FRANCE, R.L. PETERS, R.H.. Predictive model of the effects on lake metabolism of decreased airborne litterfall through riparian deforestation. Conservation Biology, 1995. Vol. 9. pp. 1578-1586.

FRANCE, R.L., STEEDMAN, R.J. Energy provenance for juvenile lake trout in small Canadian Shield lakes as shown by stable isotopes. Transactions of the American Fisheries Society, 1996. Vol. 125. pp. 512-518.

FRANCE, R., YAN, N., OLESIUK, P., NERO, R. DEL GIORGIO, P. Secondary analysis of relationships between pelagic invertebrate predators and phytoplankton abundance and water clarity. Freshwater Biology, 1995. Vol. 34. pp. 255-261.

FRANCE, R., CULBERT, H. PETERS, R.. Decreased carbon and nutrient input to boreal lakes from particulate organic matter following riparian clearcutting. Environ. Management, 1996. Vol. 20. pp. 579-583.

FRANCE, R.L., FREEBOROUGH, C., PETERS, R.. Leaching and early mass loss of boreal leaves and wood in oligotrophic water. Hydrobiologia, 1997. Vol. 345. pp. 209-214.

FRANCE, R., PETERS, R., MCCABE, L. Spatial relationships among boreal riparian trees, litterfall and soil erosion potential with reference to buffer strip management 
and coldwater fisheries. Annals Botanni Fennici, 1998. Vol. 35. pp. 1-9.

FRANCE, R., STEEDMAN, R., LEHMANN, R., PETERS, R. Influence of catchment timber harvesting on average total phosphorus concentration in boreal forest lakes. Verh International Verein Limnology, 2000a. Vol. 27. pp. 1560-1563.

FRANCE，R., STEEDMAN, R., LEHMANN, R. PETERS, R. Landscape modification of DOC concentration in boreal lakes: implications for UV-B sensitivity. Water, Air and Soil Pollution, 2000b. Vol. 122. pp. 153-162.

GHADOUANI, A., PINEL-ALLOUL, B., PREPAS, E.E. Could increased cyanobacterial biomass following forest harvesting cause a reduction in zooplankton body size structure? Canadian Journal of Fisheries and Aquatic Sciences, 2006. Vol. 63. pp. 2308-2317.

GREEN, R.H. Lipid and caloric contents of the relict amphipod Pontoporeia affinis in Cayuga lake, N.Y. Journal of the Fisheries Research Board of Canada, 1971. Vol. 28. pp. 776-777.

GUIGUER, K., BARTON, D.R. The trophic role of Diporeia (Amphipoda) in Colpoys Bay (Georgian Bay) benthic food web: a stable isotope approach. Journal of Great Lakes Research. 2002, Vol. 28. pp. 228-239.

HONDORP, D.W., POTHOVER, S.A., BRANDT, S.B. Influence of Diporeia density on diet composition, relative abundance, and energy density of planktivorous fishes in southwest Lake Michigan, Journal of the American Fisheries Society. 2005, Vol. 134. pp. 588-601.

KNAPP, C.W., GRAHAM, D.W., STEEDMAN, R.J., DENOYELLES, F. Deep chlorophyll maxima in small boreal forest lakes after experimental catchment and shoreline logging. Boreal Environment Research, 2003, vol. 87. pp. 9-18.

MCEACHERN, P., PREPAS, E.E., GIBSON, J.J. , DINSMORE, W.P. Forest fire induced impacts on phosphorus, nitrogen, and chlorophyll a concentrations in boreal subarctic lakes of northern Alberta, Canadian Journal of Fisheries and Aquatic Sciences. 2000, Vol. 57. pp. 73-81.

NERO, R.W. Comparison of two sampling methods for estimating the abundance and distribution of Mysis relicta. Canadian Journal of Fisheries and Aquatic Sciences, 1982. Vol. 39. pp. 349-355.

NERO, R.W., SCHINDLER, D.W. Decline of Mysis relicta during acidification of Lake 223. Canadian Journal of Fisheries and Aquatic Sciences, 1986. Vol. 40. pp. 19051911.

NERO, R.W., SPRULES, W.G. Zooplankton species abundance and biomass in relation to occurrence of Mysis relicta (malacostraca: Mysidacea). Canadian Journal of Fisheries and Aquatic Sciences, 1986. Vol. 43. pp. 420-434.

NICHOLLS, K.H., STEEDMAN, R.J., CARNEY, E.C. Changes in phytoplankton communities following logging in the drainage basins of three boreal forest lakes in northwestern Ontario (Canada), 1991-2000. Canadian Journal of Fisheries and Aquatic Sciences, 2003. Vol. 60. pp. 43-54.

PATERSON, A.W., CUMMING, B.F., SMOL, J.P., BLAIS, J.M. FRANCE, R.L. Assessment of the effects of logging, forest fires and drought on lakes in northwestern Ontario: a 30-year paleolimnological perspective, Canadian Journal of Forest Research, 1998, Vol. 28, pp. 1546-1556.

PATOINE, A., PINEL-ALLOUL, B., CARIGNAN, R. Do logging and forest fires influence zooplankton biomass in Canadian Boreal Shield lakes? Canadian Journal of Fisheries and Aquatic Sciences, 2000. Vol. 57. pp. 155164.

PATOINE, A., PINEL-ALLOUL, B., PREPAS, E. Effects of catchment perturbations by logging and wildfires on zooplankton species richness and composition in Boreal Shield lakes. Freshwater Biology, 2002. Vol. 47. pp. 19962014.

PATOINe, A., PINEL-ALlOUL, B., PREPAS, E. Influence of catchment deforestation by logging and natural forest fires on crustacean community size structure in lakes of the Eastern Boreal Canadian forest. Journal of Plankton Research, 2002. Vol. 6. pp. 601-616.

PERERA, A.H., EULER, D.L., THOMPSON, I.D. Ecology of a Managed Terrestrial Landscape: Patterns and Processes of Forest Landscapes in Ontario, 2000. UBC Press.

PINEL-ALLOUL, B., PREPAS, E., PLANAS, D. STEEDMAN, R., CHARETTE, T. Watershed impacts of logging and wildfire: case studies in Canada. Lake and Reservoir Management, 2002. Vol. 18. Pp. 307-318.

PLANAS, D., DESROSIERS, M., GROUIX, S., PAQUET, S., CARIGNAN, R. Pelagic and benthic algal responses in eastern Canadian Boreal Shield lakes following harvesting and wildfires. Canadian Journal of Fisheries and Aquatic Sciences, 2000. Vol. 57. pp. 136-145.

RASANEN, J., KENTTAMIES, K., SANDMAN, O. Paleolimnological assessment of the impact of logging on small boreal lakes. Limnologica, 2007. Vol. 37. pp. 193207.

RASK, M., NYBERG, K., MARKKANEN, S., OJALA, A. Forestry in catchments: effects on water quality, plankton, zoobenthos and fish in small lakes. Boreal Environment Research, 1998. Vol. 3. pp. 75-86.

SCHINDLER, D.W. Experimental perturbations of whole lakes as tests of hypotheses concerning ecosystem structure and function. Oikos, 1990. Vol. 57. pp. 25-41.

SCULLY, N.M., LEAVITT, P.R., CARPENTER, S.R. Century-long effects of forest harvest on the physical structure and autotrophic community of a small temperate lake. Canadian Journal of Fisheries and Aquatic Sciences, 2000. Vol. 57. pp. 50-59.

ST. ONGE, I., MAGNAN, P. Impact of logging and natural fires on fish communities of Laurentian Shield lakes. Canadian Journal of Fisheries and Aquatic Sciences, 2000. Vol. 57. pp. 165-174.

STEEDMAN, R.J. Effects of experimental clearcut logging on water quality in three small boreal forest lake trout (Salvelinus namaycush) lakes. Canadian Journal of Fisheries and Aquatic Sciences, 2000. Vol. 57. pp. 92-96.

STEEDMAN, R.J. Littoral fish response to experimental logging around small Boreal Shield lakes. North American Journal of Fisheries Management, 2003. Vol. 23. pp. 392-403.

STEEDMAN, R.J., KUSHNERIUK, R.S. Effects of experimental clearcut logging on thermal stratification, dissolved oxygen, and lake trout (Salvelinus namaycush) habitat volume in three small boreal forest lakes. Canadian Journal of Fisheries and Aquatic Sciences, 2000. Vol. 57. pp. 82-91.

STEEDMAN, R.J., FRANCE, R.L. Origin and transport of Aeolian sediment from new clearcuts into boreal lakes, northwestern Ontario, Canada. Water, Air and Soil Pollution, 2000. Vol. 122. pp. 139-152.

STEEDMAN, R.J., ALLAN, C.J., FRANCE, R.L., KUSHNERIUK, R.S. Land, water, and human activity on Boreal watersheds. In Gunn, J.M., Steedman, R.J., Ryder, R.A. (eds.) Boreal Shield Watersheds: Lake Trout Ecosystems in a Changing Environment, 2004. CRC Press.

TONN, W.M., PASZOWSKI, C.A., SCRIMGEOUR, G.L., AKU, P., LANGE, M., PREPAS, E.E., WESTCOTT, $\mathrm{K}$. Effects of forest harvesting and fire on fish assemblages in Boreal Plains lakes: a reference condition approach. 
Transactions of the American Fisheries Society, 2004. Vol. 132. pp. 504-523.

WINKLER, G., LECLERC, V., SIROIS, P., ARCHAMBAULT, P. BERUBE, P. Short-term impact of forest harvesting on water quality and zooplankton communities in oligotrophic headwater lakes of the eastern Canadian Boreal Shield. Boreal Environment Research, 2009. Vol. 14. pp. 323-337.
Dr. R. L. France, Associate Professor at Integrated Environmental Management, Department of Engineering, NSAC, Truro, Nova Scotia, Canada; Department of Graduate Studies, Dalhousie University, Halifax, Nova Scotia, Canada; Center for Technology and the Environment, Harvard University, Cambridge, Massachusetts, USA.

Main research areas: aquatic repercussions of riparian forestry, aquatic remediation of disturbed sites and design of artificial lakes, wetland creation and restoration.

E-mail: $\quad$ rfrance@nsac.ca

\title{
Vèžiagyvių paplitimas borealinès zonos ežerų profundalèje ir pelagialėje prieš eksperimentinị miško kirtimą ir po jo
}

\author{
R. L. France \\ Inžinerijos fakultetas, NSAC, Kanada \\ Dalhauzo universitetas, Kanada \\ Technologijų ir aplinkos apsaugos centras, Harvardo universitetas, JAV
}

(gauta 2011 m. balandžio mèn.; atiduota spaudai 2011 m. birželio mèn.)

Devynerių metų stebėjimų rezultatai rodo, kad trijuose borealinès zonos ežeruose aptinkama krevečių Mysis relict ir šoniplaukų Diporeia hoyi, nepaisant to, ar baseino miškai yra neliečiami, paliekami kaip apsauginè juosta, ar beveik visiškai iškertami. Nustatytas Diporeia pagausèjimas tuose ežeruose, prie kurių buvo atlikti kirtimo darbai.Viename iš ežeru Mysis sumažejimas nustatytas prieš atliekant kirtimo darbus. Tyrimas parodè, kad minètos nuo ledynmečio išlikusios vėžiagyvių rūšys nẻra neigiamai veikiamos miškų kirtimų, priešingai, nei šios rūšies vėžiagyvių didelis jautrumas ir nykimas rūgštejjančiuose borealinės zonos ežeruose. 